Marquette University

e-Publications@Marquette

$1-1-2014$

Limiting the Mortgage Interest Deduction by Size of Home: Effects on the User Cost and Price of Housing Across Metropolitan Areas

Andrew Hanson

Marquette University, andrew.r.hanson@marquette.edu

Published version. Journal of Housing Research, Vol. 23, No. 1 (2014): 1-20. Publisher Link. (C) 2014

American Real Estate Society. Used with permission. 


\section{Limiting the Mortgage Interest Deduction by Size of Home: Effects on the User Cost and Price of Housing Across Metropolitan Areas}

\section{Andrew Hanson}

\section{Abstract}

In this paper, I examine the user cost and home price implications of limiting the federal mortgage interest deduction (MID) based on the square footage of a home. I extend the standard user cost model to include a square footage-based cap on the tax-favored status of mortgage interest. I compare two policy alternatives: one that limits the marginal deduction based on home size, and another that removes the deduction on the home based on home size. There is substantial variation across metropolitan areas in both the number of homes exposed to each type of cap, the user cost increase, and the resulting expected price declines.

The mortgage interest deduction (MID) is the largest housing-related subsidy in the United States federal budget, allowing forgone revenue of over $\$ 104$ billion in fiscal year 2011 (Executive Office of the President, 2010). Recently, several proposals have been made to limit the MID by capping ${ }^{1}$ the amount of interest that qualifies for a deduction from taxable income. In 2005, President George W. Bush's Tax Reform Panel suggested replacing the MID with a $15 \%$ tax credit and limiting the size of mortgage available for the credit based on regional home prices. More recently, the National Commission on Fiscal Responsibility and Reform (commonly referred to as the Bowles-Simpson Commission) recommended switching the MID to a $12 \%$ tax credit and lowering the size of eligible mortgage to $\$ 500,000$. Another recent proposal, conceived by Congressmen John Dingell (D-MI) ${ }^{2}$ suggests limiting the MID based on the square footage of a home, rather than by the amount borrowed.

Part of the motivation behind targeting large homes, rather than debt financing, is that the size of homes has grown substantially in the last 30 years, resulting in externalities from decreased density, further commuting, and increased energy use for heating and cooling larger spaces. According to the National Association of Homebuilders, the average square footage for a new single-family home completed in 2009 was 2,438. This represents an increase of more than 350 square feet from the average in 1990 and an increase of almost 700 square feet from the average in $1980 .{ }^{3}$ The mechanism for reducing the size of homes in changing the MID is to increase the cost of owning a larger home, thus discouraging home purchase on the extensive margin.

An academic discussion of eliminating or capping the MID has been on-going for some time (e.g., Woodward and Weicher, 1989; Follain and Melamed, 1998; Green and Vandell, 
1999; Anderson, Clemens, and Hanson, 2007; and Poterba and Sinai, 2008). Proponents of the MID argue that it eliminates the distortion that would otherwise occur in the tax code between debt and equity financing of a home. Opponents argue that a deduction is not appropriate unless the imputed rental income from housing is taxed, and that the MID is unwisely targeted and does not promote ownership because it is most valuable to upper income households who itemize deductions and those facing higher marginal tax rates. ${ }^{4}$

In this paper, I make three contributions to the discussion on changing MID policy. First, I extend the familiar user cost model of housing to include a MID cap based on the square footage of a home. Second, I use the updated model to determine how limiting the MID based on square footage would affect the annual cost of homeownership and home price levels nationally and across metropolitan areas. Third, I compare changes across metropolitan areas for two policy alternatives: a cap that phases out the entire value of the MID on a sliding scale as the square footage of a home increases, as Dingell's proposal called for (referred to as a clawback cap), and a flat national square footage cap. Estimating the user cost impact of proposed policy is crucial, as it is the cost of owning increase that will elicit any change in the size of home purchased by consumers.

Using data from the American Housing Survey on the square footage of homes, I simulate the share of homes exposed to each size-based MID cap. A national cap on the MID for square footage over 3,000 square feet is binding for about $9.4 \%$ of homes throughout the U.S. Under the flat cap policy alternative, removing the deduction on marginal borrowing would increase user cost by $7.8 \%$. The user cost increase from the flat cap across metropolitan areas would range from a low of $1.3 \%$ in Rochester, New York to a high of $17.1 \%$ in Riverside, California. Under the clawback cap, user cost would increase by $17.3 \%$ nationally. The user cost increase from the clawback cap across metropolitan areas would range from a low of $4.7 \%$ in Rochester, New York to a high of $38.8 \%$ in Riverside, California. Nationally, these user cost changes would translate into expected price declines on homes exposed to the clawback cap of $\$ 67,834$, and range from a decline of $\$ 196,171$ in San Diego, California to a decline of $\$ 10,071$ in Rochester, New York. Expected price declines under the flat cap are about half the magnitude of declines under the clawback proposal, averaging $\$ 33,507$ nationally, and ranging from $\$ 2,918$ in Rochester, New York to $\$ 98,039$ in San Diego, California.

The remainder of the paper proceeds as follows. In the next section, I outline the user cost model adjusted for a square footage based MID cap. In the third section, I present the simulation results for proposals that limit the MID based on the square footage of a home. In the fourth section, I discuss other aspects of limiting the MID based on square footage. The final section is a concluding commentary.

\section{User Cost Model Adjusted for MID Square Footage Limit}

The standard user cost model ${ }^{5}$ of housing represents the annual profit from homeownership $(A)$ as the difference between imputed rental value, $R$, and the annual costs associated with owning a home as they relate to the purchase price, $P_{H}$. Although notation sometimes differs, some form of the following equation typically represents the model: 


$$
A=R-\left[(1-\tau) \tau_{p}+(1-\tau)(1-\theta) i_{1}+(1-\tau) \theta i_{2}+m-\pi\right] P_{H},
$$

where $\tau_{p}$ is the annual property tax rate, $\tau$ is the marginal income tax rate (a function of annual income), $\theta$ is the share of the house that is financed with debt (where $\theta \leq 1$ ), $i_{1}$ is the interest rate that would be earned on an alternative asset, $i_{2}$ is the interest rate paid on a mortgage, $m$ is annual maintenance costs, and $\pi$ is house price inflation net of depreciation. Equation (1) accounts for the mortgage interest deduction as well as the deduction for property taxes, both of which reduce the cost of homeownership.

In equilibrium, the annual profit from homeownership equals zero. Equation (2) represents the rental price of housing after setting $A$ equal to zero:

$$
R=\left[(1-\tau) \tau_{p}+(1-\tau)(1-\theta) i_{1}+(1-\tau) \theta i_{2}+m-\pi\right] P_{H}
$$

\section{Flat Cap on Square Footage}

Capping the mortgage interest deduction by the size of the home changes the third term in equation (2) by creating a relative price difference between purchasing square footage with debt financing below the limit, and above the limit. The term $S q$ reflects this difference, where:

$$
\begin{aligned}
S q & =(\text { Total Square Footage } \\
& - \text { Square Footage Limit) } /(\text { Total Square Footage) if (Total Square Footage } \\
& - \text { Square Footage Limit) } \geq 0, S q=0 \text { otherwise. }
\end{aligned}
$$

$S q$ represents the share of the home above the square footage limit. Note that any housing financed with equity is not subject to the differential price caused by a square footage cap. With the introduction of a flat square footage cap on the MID, the third term in equation (2) splits into the share that retains the mortgage interest deduction, $(1-S q)$ and the share that is no longer deductible, $S q$, where $S q \leq 1$, resulting in:

$$
R_{c a p}=\left[(1-\tau) \tau_{p}+(1-\tau)(1-\theta) i_{1}+S q \theta i_{2}+(1-S q)(1-\tau) \theta i_{2}+m-\pi\right] P_{H}
$$

Notice that the third and fourth terms in equation (3) represent the difference in the price of financing with debt above (third term) and below (fourth term) the square footage cap. In order to relate the square footage cap to the user cost model, I must assume that the mortgage interest rate is constant for all square footage of a particular house. Conceivably, I could relax this assumption if I knew how the mortgage interest rate changes with square footage for each house. For the current purpose, this assumption is reasonable, as I examine the average user cost change at the metropolitan area level. ${ }^{6}$ Applying the same interest rate to all square footage in this way mimics current law treatment on debt financed housing and the interaction with current MID limits. The annual increase in the user cost of homeownership resulting from the flat square footage cap equals:

$$
R_{\text {cap }}-R=\tau\left(S q \theta i_{2}\right) P_{H}
$$

The annual increase in user cost depends on a taxpayer's marginal tax rate, $t$, which increases with income. The marginal cost of purchasing an additional square foot of 
housing, financed with debt, over the limit increases from $(1-\tau) i_{2}$ to $i_{2}$ with the limit in place. The increase in marginal cost will be greater for those with a higher marginal tax rate (taxable income). In effect, the policy places a tax of $\tau i_{2}$ on purchasing square footage financed with debt above the limit.

Solving the user cost model for price changes instead of user cost changes, yields a price difference of:

$$
P_{H \text { cap }}-P_{H}=-\tau\left(S q \theta i_{2}\right) R /\left(C_{c a p} C\right) \text {. }
$$

Where $C_{\text {cap }}$ represents the term in brackets in equation (4) and $C$ represents the term in brackets in equation (2).

\section{MID Clawback Proposal}

Another policy alternative, presented by Representative John Dingell (D-MI), also involves capping the mortgage interest deduction based on the square footage of a home, but would remove the deduction on the entire home as size increases. This proposal again changes the third term in equation (2); however, it does so differently than the flat cap. Dingell's proposal calls for the elimination of the mortgage interest deduction on the entire home as the size of home increases, in effect "clawing-back" the existing deduction. The clawback cap phases out the MID according to the following schedule: $100 \%$ of deduction available for homes less than 3,000 sq. $\mathrm{ft}$.; $85 \%$ of deduction available for homes 3,000-3,199 sq. ft.; $70 \%$ of deduction available for homes 3,200-3,399 sq. ft.; $55 \%$ of deduction available for homes 3,400-3,599 sq. $\mathrm{ft}$.; $40 \%$ of deduction available for homes $3,600-3,799$ sq. ft. $25 \%$ of deduction available for homes $3,800-3,999$ sq. $\mathrm{ft}$.; $10 \%$ of deduction available for homes 4,000-4,199 sq. $\mathrm{ft}$.; and $0 \%$ of deduction available for homes larger than $4,200 \mathrm{sq}$. $\mathrm{ft}$.

Equation (7) represents the user cost of housing under the clawback proposal. This equation differs from equation (4) by taking into account the removal of the entire deduction as the size of home increases with a piecewise function:

$$
R_{\text {Clawback }}=\left[(1-\tau) \tau_{p}+(1-\tau)(1-\theta) i_{1}+(1-s \tau) \theta i_{2}+m-\pi\right] P_{H} .
$$

Where, $s=\{1$, if sq. ft. $<3,000,0.85$ if $3,000 \leq$ sq. ft. $\leq 3,199,0.70$ if $3,200 \leq$ sq. ft. $\leq 3,399,0.55$ if $3,400 \leq$ sq. ft. $\leq 3,599,0.40$ if $3,600 \leq$ sq. ft. $\leq 3,799,0.25$ if $3,800 \leq$ sq. ft. $\leq 3,999,0.10$ if $4,000 \leq$ sq. ft. $\leq 4,199$, and 0 if sq. ft. $\geq 4,200\}$.

Modeling the user cost of the clawback proposal does not require an assumption about the marginal interest rate of a square foot of housing because the reduction in the MID is defined by the size of house directly. The clawback proposal causes an annual increase in the cost of homeownership with respect to the standard model equal to:

$$
R_{\text {Clawback }}-R=\tau \theta i_{2}(1-s) P_{H} .
$$

Solving the user cost model with the clawback cap for price changes instead of user cost changes, yields a price difference of:

$$
P_{H \text { Clawback }}-P_{H}=-\tau \theta i_{2}(1-s) R /\left(C_{\text {Clawback }} C\right),
$$


where $C_{\text {Clawback }}$ represents the term in brackets in equation (7) and $C$ represents the term in brackets in equation (2).

The user cost difference from the proposals increase as a taxpayer's marginal tax rate, $t$, increases. The annual cost change decreases with respect to $s$, so that larger homes experience a larger cost increase. Exhibit 1 shows how both proposals change the average user cost for housing over the 3,000 square foot cap level relative to the user cost under the cap. The clawback proposal would create a lumpy pattern in average user cost because removing the deduction follows a step function. The marginal cost (the slope of each line) is large under the clawback proposal where changes in $s$ would occur, but otherwise follows the same pattern that occurs with no policy change. The flat cap would create a smooth increase in average cost after home size reaches the cap, meaning marginal cost above the cap would be constant but greater than below the cap.

Both user cost models represent static changes in user cost in that they do not account for any potential changes to mortgage interest rates or the share of home financed with debt that may result if the MID is removed or reduced. If removing the MID results in lower interest rates (because buyers and sellers split the incidence) or less debt financing, these static estimates will over-estimate the true user cost increase from limiting the MID. There is some empirical evidence that this may be the case, as Hanson (2012) shows that mortgage lenders are able to charge higher interest rates as a result of the MID, and the lenders receive between $9 \%$ and $17 \%$ of the subsidy.

\section{Simulation Results}

\section{Background, Data, and Model Parameters}

I simulate the effect of both the flat national cap, as well as the clawback proposal with the user cost model adjusted for the square footage cap. To simulate the effect of the different limits on the user cost of housing, I use data from the American Housing Survey (AHS) on the square footage of homes both nationally and across metropolitan areas. Simulations are based on parameter values (interest rate, tax rate, share of debt financing) that vary across metropolitan areas.

The AHS conducts housing stock surveys every other year nationally, as well as for select metropolitan areas on a rotating basis. ${ }^{8}$ The metropolitan-level surveys do not include all major cities. To estimate user cost changes in cities not covered by the metropolitan-level survey, I sample major omissions from the national-level survey. ${ }^{9}$ For all of the results that follow, I use the most recent AHS survey data available for a given metropolitan area. The year and sample size are detailed in Appendix Exhibit 1A. The AHS samples include both single-family and multi-family units, as well as both rental and owner-occupied units. Although renters are not able to claim the MID, it is still appropriate to use these units to examine the effect on user cost as owners of rental property can claim a deduction for mortgage expenses, and they may be the most sensitive to changing size of dwelling if they are able to divide larger units.

The sample size of the AHS Metropolitan Survey varies between 2,100 and 5,100 homes in each metro area. Data on the square footage of each unit comes from the occupant; 


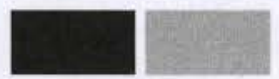

Exhibit 1. Average User Cost per Square Foot of Housing Under Clawback and Flat Cap Proposal (percentage of user cost below cap)

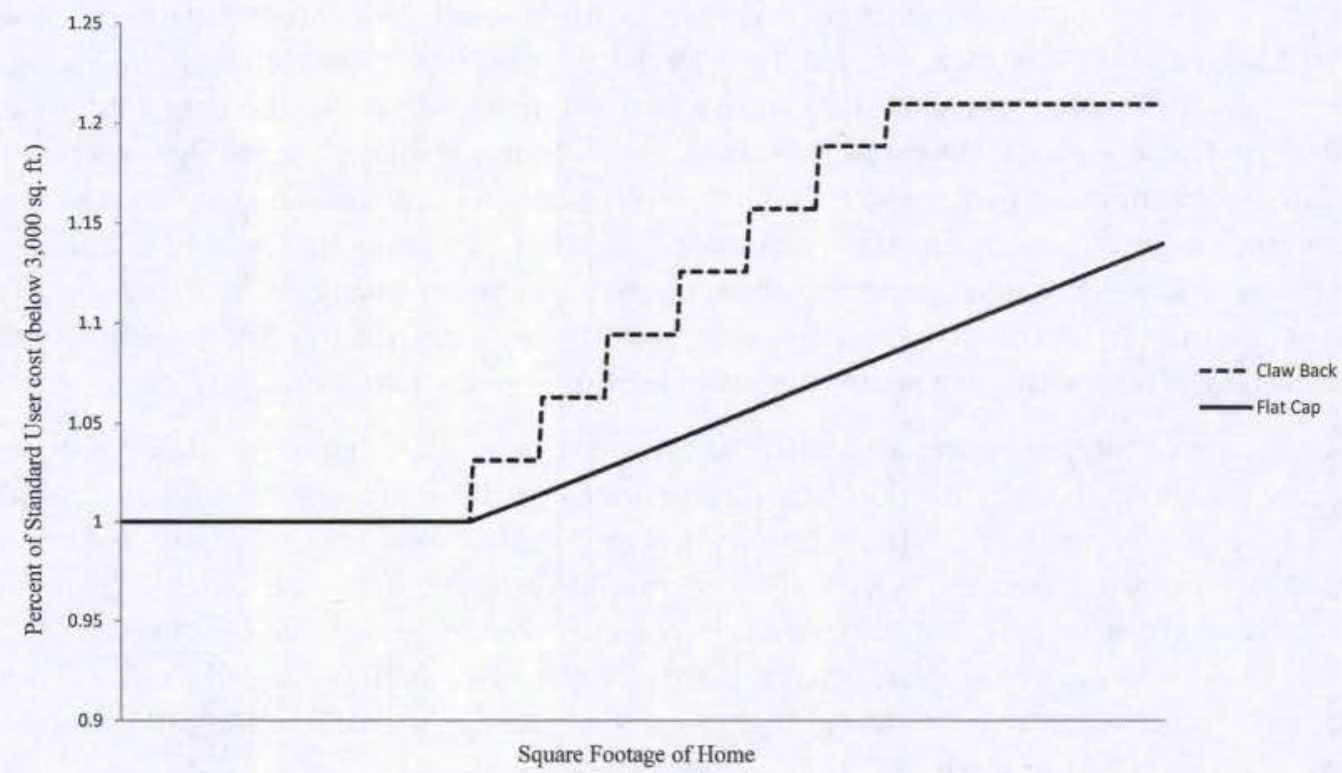

interviewers check the accuracy using exterior measurements with permission. ${ }^{10}$ Each home in the sample represents a number of other homes in the area through a weighting process. To estimate the total number of homes in the metro area as well as the number above the square footage caps, I use the weights provided with each observation. The results in Exhibits 2-4 reflect the standard weighting in the AHS survey.

The sample size in the AHS for some of the square footage categories in the clawback proposal is quite limited, and in some cities, there are no observations in certain categories. For instance, in the San Jose sample, there are no homes over 3,600 square feet and in the Norfolk Virginia sample there are no homes over 4,000 square feet. Fortunately, most metro areas have at least some homes in the sample in each category outlined in the proposal; however, for those that do not, estimates for the number of homes over the cap and the user cost parameters will be underestimates if there are actually homes of this size in the area.

I create estimates of the $S q$ parameter for the flat 3,000 square foot cap for each metro area. I estimate the average $S q$ parameter for each metro area in two ways: first a true metro average that includes those homes that have $S q$ equal to zero, and then the average $S q$ for only homes that are above the cap. I estimate the average $(1-s)$ parameter from the clawback proposal each of the ways I estimate $S q$. Recall that the $(1-s)$ parameter depends on which category the home falls into and reduces the deduction accordingly, the $S q$ parameter depends on how far over the cap the home is. Exhibit 2 shows the estimates of these parameters nationally and across all metropolitan areas in the sample.

The change in user cost from the policy will depend on the interaction between the home size distribution, income tax rates as they apply to the deduction (state income tax 


\begin{tabular}{|c|c|c|c|c|c|c|}
\hline \multirow[b]{2}{*}{ Metro Area } & \multirow[b]{2}{*}{$\begin{array}{l}\text { Number of } \\
\text { Homes }\end{array}$} & \multirow[b]{2}{*}{$\begin{array}{l}\% \text { of Homes } \\
\text { over } 3,000 \\
\text { Sq. Ft. }\end{array}$} & \multicolumn{2}{|c|}{$\begin{array}{l}\text { Sq Cost Change } \\
\text { Parameter }\end{array}$} & \multicolumn{2}{|c|}{$\begin{array}{l}(1-s) \text { Cost Change } \\
\text { Parameter }\end{array}$} \\
\hline & & & $\begin{array}{l}\text { Average } \\
\text { Including } \\
\text { Zero } \\
\text { Changes }\end{array}$ & $\begin{array}{l}\text { Average, } \\
\text { Above } \\
\text { Cap } \\
\text { Only }\end{array}$ & $\begin{array}{l}\text { Average } \\
\text { Including } \\
\text { Zero } \\
\text { Changes }\end{array}$ & $\begin{array}{l}\text { Average } \\
\text { Above } \\
\text { Cap } \\
\text { Only } \\
\end{array}$ \\
\hline & (1) & (2) & (3) & (4) & (5) & (6) \\
\hline NATIONAL & $128,203,134$ & $9.46 \%$ & 0.027 & 0.284 & 0.056 & 0.596 \\
\hline Anaheim-Santa Ana, CA & 995,557 & $5.98 \%$ & 0.014 & 0.245 & 0.034 & 0.571 \\
\hline Atlanta, GA & $1,842,131$ & $15.58 \%$ & 0.045 & 0.288 & 0.098 & 0.631 \\
\hline Baltimore, MD & $1,028,133$ & $15.53 \%$ & 0.044 & 0.288 & 0.097 & 0.626 \\
\hline Birmingham, AL & 394,033 & $10.43 \%$ & 0.020 & 0.191 & 0.064 & 0.616 \\
\hline Boston, MA & $1,150,506$ & $10.92 \%$ & 0.029 & 0.269 & 0.068 & 0.621 \\
\hline Buffalo, NY & 515,489 & $7.89 \%$ & 0.018 & 0.232 & 0.044 & 0.562 \\
\hline Charlotte, NC & 667,824 & $9.50 \%$ & 0.026 & 0.278 & 0.055 & 0.583 \\
\hline Chicago, IL & $2,256,039$ & $8.33 \%$ & 0.014 & 0.332 & 0.050 & 0.602 \\
\hline Cincinnati, $\mathrm{OH}$ & 647,516 & $8.49 \%$ & 0.016 & 0.186 & 0.050 & 0.587 \\
\hline Cleveland, $\mathrm{OH}$ & 870,831 & $9.45 \%$ & 0.023 & 0.245 & 0.053 & 0.556 \\
\hline Columbus, $\mathrm{OH}$ & 682,550 & $7.50 \%$ & 0.018 & 0.246 & 0.041 & 0.545 \\
\hline Dallas, TX & $1,365,398$ & $9.68 \%$ & 0.023 & 0.236 & 0.052 & 0.535 \\
\hline Denver, CO & 956,551 & $14.51 \%$ & 0.033 & 0.232 & 0.087 & 0.600 \\
\hline Detroit, MI & $1,877,140$ & $10.17 \%$ & 0.028 & 0.299 & 0.060 & 0.587 \\
\hline Ft. Worth-Arlington, TX & 639,381 & $7.82 \%$ & 0.020 & 0.268 & 0.043 & 0.553 \\
\hline Hartford, CT & 502,397 & $9.92 \%$ & 0.027 & 0.275 & 0.055 & 0.558 \\
\hline Houston, TX & $2,159,482$ & $9.95 \%$ & 0.025 & 0.256 & 0.053 & 0.533 \\
\hline Indianapolis, IN & 755,605 & $10.65 \%$ & 0.029 & 0.275 & 0.064 & 0.598 \\
\hline Kansas City, MO & 896,882 & $10.27 \%$ & 0.027 & 0.269 & 0.062 & 0.606 \\
\hline Los Angeles, CA & $3,297,536$ & $5.32 \%$ & 0.016 & 0.310 & 0.031 & 0.581 \\
\hline Memphis, TN & 501,041 & $9.28 \%$ & 0.023 & 0.251 & 0.053 & 0.573 \\
\hline Miami-Ft. Lauderdale, FL & $1,329,121$ & $13.88 \%$ & 0.043 & 0.318 & 0.088 & 0.633 \\
\hline Milwaukee, WI & 626,507 & $15.16 \%$ & 0.031 & 0.208 & 0.082 & 0.544 \\
\hline Minneapolis-St. Paul, MN & $1,329,150$ & $13.55 \%$ & 0.032 & 0.244 & 0.076 & 0.560 \\
\hline New Orleans, LA & 587,080 & $7.50 \%$ & 0.023 & 0.315 & 0.045 & 0.602 \\
\hline New York, NY & $3,574,469$ & $4.25 \%$ & 0.014 & 0.373 & 0.026 & 0.613 \\
\hline Norfolk, VA & 632,124 & $5.19 \%$ & 0.007 & 0.134 & 0.026 & 0.499 \\
\hline Oakland, CA & 895,037 & $5.37 \%$ & 0.007 & 0.132 & 0.027 & 0.501 \\
\hline Oklahoma City, OK & 503,036 & $5.13 \%$ & 0.014 & 0.273 & 0.032 & 0.619 \\
\hline Philadelphia, PA & $1,943,954$ & $13.56 \%$ & 0.049 & 0.356 & 0.087 & 0.640 \\
\hline Phoenix, AZ & $1,340,345$ & $6.69 \%$ & 0.021 & 0.313 & 0.039 & 0.590 \\
\hline Pittsburgh, PA & $1,085,345$ & $8.84 \%$ & 0.024 & 0.267 & 0.053 & 0.604 \\
\hline Portland, OR & 811,747 & $7.37 \%$ & 0.018 & 0.243 & 0.040 & 0.547 \\
\hline Providence, RI & 415,381 & $4.82 \%$ & 0.009 & 0.185 & 0.029 & 0.604 \\
\hline Riverside, CA & $1,229,407$ & $5.00 \%$ & 0.015 & 0.290 & 0.033 & 0.659 \\
\hline Rochester, NY & 448,531 & $6.61 \%$ & 0.008 & 0.124 & 0.029 & 0.444 \\
\hline
\end{tabular}


Exhibit 2. Effect of Square Footage Cap on MID Across Metro Areas (continued)

\begin{tabular}{|c|c|c|c|c|c|c|}
\hline \multirow[b]{2}{*}{ Metro Area } & \multirow[b]{2}{*}{$\begin{array}{l}\text { Number of } \\
\text { Homes }\end{array}$} & \multirow[b]{2}{*}{$\begin{array}{l}\% \text { of Homes } \\
\text { over } 3,000 \\
\text { Sq. Ft. }\end{array}$} & \multicolumn{2}{|c|}{$\begin{array}{l}\text { Sq Cost Change } \\
\text { Parameter }\end{array}$} & \multicolumn{2}{|c|}{$\begin{array}{l}(1-s) \text { Cost Change } \\
\text { Parameter }\end{array}$} \\
\hline & & & $\begin{array}{l}\text { Average } \\
\text { Including } \\
\text { Zero } \\
\text { Changes }\end{array}$ & $\begin{array}{l}\text { Average, } \\
\text { Above } \\
\text { Cap } \\
\text { Only }\end{array}$ & $\begin{array}{l}\text { Average } \\
\text { Including } \\
\text { Zero } \\
\text { Changes }\end{array}$ & $\begin{array}{l}\text { Average } \\
\text { Above } \\
\text { Cap } \\
\text { Only }\end{array}$ \\
\hline & (1) & (2) & (3) & (4) & (5) & (6) \\
\hline Sacramento, CA & 744,470 & $6.55 \%$ & 0.019 & 0.301 & 0.038 & 0.583 \\
\hline Salt Lake City, UT & 443,995 & $16.38 \%$ & 0.029 & 0.181 & 0.097 & 0.591 \\
\hline San Antonio, TX & 659,374 & $5.72 \%$ & 0.018 & 0.315 & 0.032 & 0.561 \\
\hline San Diego, CA & $1,071,968$ & $4.94 \%$ & 0.013 & 0.273 & 0.032 & 0.643 \\
\hline San Francisco, CA & 700,195 & $5.18 \%$ & 0.006 & 0.111 & 0.021 & 0.396 \\
\hline San Jose, CA & 591,432 & $4.29 \%$ & 0.003 & 0.082 & 0.015 & 0.341 \\
\hline Seattle, WA & $1,091,962$ & $9.02 \%$ & 0.022 & 0.247 & 0.049 & 0.544 \\
\hline St. Louis, MO & $1,167,471$ & $12.90 \%$ & 0.031 & 0.241 & 0.078 & 0.604 \\
\hline Tampa-St. Petersburg, FL & $1,322,437$ & $5.54 \%$ & 0.022 & 0.402 & 0.035 & 0.627 \\
\hline Washington, DC & $2,133,221$ & $17.64 \%$ & 0.047 & 0.268 & 0.113 & 0.640 \\
\hline
\end{tabular}

Notes: The source is authors' calculations using American Housing Survey Metro and National Data Files for 1998-2007. See the Appendix for metro area definitions. The number of homes and percentage of homes over 3,000 sq. ft. are based on weighted samples. See the Appendix for sample sizes.

rates and availability of the mortgage interest deduction), differences in mortgage interest rates, and the share of debt financing as shown in equations (5) and (8). The AHS contains data on the size of original mortgage, mortgage interest rate, and house price that allows calculation of the $\theta$ and $i_{2}$ parameters. ${ }^{11} \mathrm{I}$ add data from state tax forms on availability of the MID and state marginal tax rates to create a more accurate estimate of the $t$ parameter across areas. To add detail on initial user cost, I also construct a measure of $m$ and $\tau_{p}$ with the AHS data. ${ }^{12}$

According to the AHS data, $9.46 \%$ of homes nation-wide are larger than 3,000 square feet and would lose some tax-preferred status under both the flat national cap and clawback proposal. As shown in Exhibit 2, there is substantial difference in the user cost change parameter, $S q$, when calculating it using an average of all homes versus calculating it using only the homes over the proposed limit. The difference for the user cost change parameter $(1-s)$ under the clawback proposal is even more pronounced.

\section{User Cost Changes}

The national user cost change shows how the annual cost of owning a home would increase substantially under either type of MID limit. Exhibit 3 shows how each proposal changes the user cost of housing using nationally, and across metropolitan areas. The NATIONAL row shows that the severity of the average national user cost increase depends on whether I use all homes or only those over the proposed cap. The cost change measured for only those over the cap is $17.3 \%$ annually under the clawback proposal. 
Exhibit 3. User Cost Changes Across Metro Areas

\begin{tabular}{|c|c|c|c|c|c|c|c|c|}
\hline \multirow[b]{3}{*}{ Metro Area } & \multicolumn{4}{|c|}{ User Cost With Clawback Proposal } & \multicolumn{4}{|c|}{$\begin{array}{l}\text { User Cost With Flat } 3,000 \text { Sq. Ft. } \\
\text { Cap }\end{array}$} \\
\hline & \multicolumn{2}{|c|}{ Metro Average } & \multicolumn{2}{|c|}{$\begin{array}{l}\text { Only Homes } \\
\text { Over Cap }\end{array}$} & \multicolumn{2}{|c|}{ Metro Average } & \multicolumn{2}{|c|}{$\begin{array}{l}\text { Only Homes } \\
\text { Over Cap }\end{array}$} \\
\hline & Per \$1 & $\begin{array}{l}\% \\
\text { Increase }\end{array}$ & Per \$1 & $\begin{array}{l}\% \\
\text { Increase }\end{array}$ & Per \$1 & $\begin{array}{l}\% \\
\text { Increase }\end{array}$ & Per \$1 & $\begin{array}{l}\% \\
\text { Increase }\end{array}$ \\
\hline NATIONAL & 0.054 & $1.57 \%$ & 0.062 & $17.30 \%$ & 0.053 & $0.68 \%$ & 0.057 & $7.83 \%$ \\
\hline Anaheim-Santa Ana, CA & 0.040 & $1.89 \%$ & 0.052 & $31.58 \%$ & 0.040 & $0.78 \%$ & 0.045 & $13.57 \%$ \\
\hline Atlanta, GA & 0.045 & $3.61 \%$ & 0.054 & $23.16 \%$ & 0.044 & $1.64 \%$ & 0.048 & $10.56 \%$ \\
\hline Baltimore, MD & 0.049 & $3.18 \%$ & 0.058 & $20.45 \%$ & 0.048 & $1.44 \%$ & 0.052 & $9.40 \%$ \\
\hline Birmingham, AL & 0.044 & $0.50 \%$ & 0.046 & $4.83 \%$ & 0.044 & $0.16 \%$ & 0.045 & $1.50 \%$ \\
\hline Boston, MA & 0.054 & $1.50 \%$ & 0.061 & $13.77 \%$ & 0.054 & $0.64 \%$ & 0.057 & $5.96 \%$ \\
\hline Buffalo, NY & 0.071 & $1.25 \%$ & 0.081 & $15.79 \%$ & 0.070 & $0.50 \%$ & 0.075 & $6.52 \%$ \\
\hline Charlotte, NC & 0.046 & $2.52 \%$ & 0.057 & $26.49 \%$ & 0.046 & $1.16 \%$ & 0.051 & $12.60 \%$ \\
\hline Chicago, IL & 0.060 & $1.24 \%$ & 0.069 & $14.93 \%$ & 0.060 & $0.34 \%$ & 0.065 & $8.22 \%$ \\
\hline Cincinnati, $\mathrm{OH}$ & 0.058 & $0.49 \%$ & 0.061 & $5.74 \%$ & 0.058 & $0.15 \%$ & 0.059 & $1.82 \%$ \\
\hline Cleveland, $\mathrm{OH}$ & 0.063 & $0.98 \%$ & 0.069 & $10.34 \%$ & 0.063 & $0.42 \%$ & 0.065 & $4.55 \%$ \\
\hline Columbus, $\mathrm{OH}$ & 0.056 & $1.13 \%$ & 0.064 & $15.07 \%$ & 0.056 & $0.51 \%$ & 0.059 & $6.79 \%$ \\
\hline Dallas, TX & 0.061 & $1.53 \%$ & 0.070 & $15.80 \%$ & 0.061 & $0.67 \%$ & 0.065 & $6.98 \%$ \\
\hline Denver, CO & 0.043 & $3.14 \%$ & 0.050 & $21.64 \%$ & 0.042 & $1.20 \%$ & 0.045 & $8.37 \%$ \\
\hline Detroit, MI & 0.061 & $1.56 \%$ & 0.069 & $15.37 \%$ & 0.060 & 0.7 & 0.065 & $7.82 \%$ \\
\hline Ft. Worth-Arlington, TX & 0.069 & $1.14 \%$ & 0.078 & $14.63 \%$ & 0.068 & $0.54 \%$ & 0.073 & $7.10 \%$ \\
\hline Hartford, CT & 0.066 & $1.01 \%$ & 0.072 & $10.17 \%$ & 0.065 & $0.49 \%$ & 0.068 & $5.01 \%$ \\
\hline Houston, TX & 0.067 & $1.23 \%$ & 0.075 & $12.35 \%$ & 0.067 & $0.57 \%$ & 0.071 & $5.92 \%$ \\
\hline Indianapolis, IN & 0.053 & $1.61 \%$ & 0.060 & $15.11 \%$ & 0.052 & $0.73 \%$ & 0.055 & $6.95 \%$ \\
\hline Kansas City, MO & 0.053 & $2.42 \%$ & 0.064 & $23.59 \%$ & 0.053 & & 0.057 & $10.46 \%$ \\
\hline Los Angeles, CA & 0.043 & $1.50 \%$ & 0.054 & $28.27 \%$ & 0.042 & $0.79 \%$ & 0.048 & $15.10 \%$ \\
\hline Memphis, TN & 0.055 & $1.34 \%$ & 0.062 & $14.43 \%$ & 0.055 & $0.57 \%$ & 0.058 & $6.31 \%$ \\
\hline Miami-Ft. Lauderdale, FL & 0.061 & $2.05 \%$ & 0.069 & $14.80 \%$ & 0.061 & $1.00 \%$ & 0.064 & $7.44 \%$ \\
\hline Milwaukee, WI & 0.065 & $2.46 \%$ & 0.073 & $16.21 \%$ & 0.064 & $0.92 \%$ & 0.067 & $6.20 \%$ \\
\hline Minneapolis-St. Paul, MN & 0.049 & $2.66 \%$ & 0.057 & $19.60 \%$ & 0.048 & $1.11 \%$ & 0.052 & $8.52 \%$ \\
\hline New Orleans, LA & 0.051 & $1.27 \%$ & 0.059 & $16.98 \%$ & 0.051 & $0.65 \%$ & 0.055 & $8.88 \%$ \\
\hline New York, NY & 0.053 & $0.90 \%$ & 0.064 & $21.26 \%$ & 0.053 & $0.50 \%$ & 0.060 & $12.95 \%$ \\
\hline Norfolk, VA & 0.048 & $0.52 \%$ & 0.053 & $9.94 \%$ & 0.048 & $0.14 \%$ & 0.049 & $2.66 \%$ \\
\hline Oakland, CA & 0.041 & $0.67 \%$ & 0.046 & $12.43 \%$ & 0.041 & $0.17 \%$ & 0.042 & $3.27 \%$ \\
\hline Oklahoma City, OK & 0.047 & $1.30 \%$ & 0.058 & $25.28 \%$ & 0.046 & $0.56 \%$ & 0.051 & $11.13 \%$ \\
\hline Philadelphia, PA & 0.064 & $2.17 \%$ & 0.073 & $16.00 \%$ & 0.064 & $1.21 \%$ & 0.069 & $8.90 \%$ \\
\hline Phoenix, AZ & 0.041 & $2.01 \%$ & 0.053 & $30.08 \%$ & 0.041 & $1.09 \%$ & 0.047 & $15.99 \%$ \\
\hline Pittsburgh, PA & 0.075 & $0.86 \%$ & 0.082 & $9.76 \%$ & 0.075 & $0.38 \%$ & 0.078 & $4.32 \%$ \\
\hline Portland, OR & 0.047 & $1.85 \%$ & 0.058 & $25.03 \%$ & 0.046 & $0.80 \%$ & 0.051 & $11.09 \%$ \\
\hline Providence, RI & 0.064 & $0.28 \%$ & 0.068 & $5.86 \%$ & 0.064 & $0.08 \%$ & 0.065 & $1.79 \%$ \\
\hline Riverside, CA & 0.041 & $1.94 \%$ & 0.056 & $38.83 \%$ & 0.041 & $0.86 \%$ & 0.047 & $17.12 \%$ \\
\hline Rochester, NY & 0.072 & $0.32 \%$ & 0.076 & $4.78 \%$ & 0.072 & $0.09 \%$ & 0.073 & $1.34 \%$ \\
\hline Sacramento, CA & 0.041 & $1.63 \%$ & 0.051 & $24.83 \%$ & 0.041 & $0.82 \%$ & 0.046 & $12.80 \%$ \\
\hline
\end{tabular}




\section{Exhibit 3. User Cost Changes Across Metro Areas (continued)}

\begin{tabular}{|c|c|c|c|c|c|c|c|c|}
\hline \multirow[b]{3}{*}{ Metro Area } & \multicolumn{4}{|c|}{ User Cost With Clawback Proposal } & \multicolumn{4}{|c|}{$\begin{array}{l}\text { User Cost With Flat } 3,000 \mathrm{Sq} . \text { Ft. } \\
\text { Cap }\end{array}$} \\
\hline & \multicolumn{2}{|c|}{ Metro Average } & \multicolumn{2}{|c|}{$\begin{array}{l}\text { Only Homes } \\
\text { Over Cap }\end{array}$} & \multicolumn{2}{|c|}{ Metro Average } & \multicolumn{2}{|c|}{$\begin{array}{l}\text { Only Homes } \\
\text { Over Cap }\end{array}$} \\
\hline & Per \$1 & $\begin{array}{l}\% \\
\text { Increase }\end{array}$ & Per \$1 & $\begin{array}{l}\% \\
\text { Increase }\end{array}$ & Per \$1 & $\begin{array}{l}\% \\
\text { Increase }\end{array}$ & Per \$1 & $\begin{array}{l}\% \\
\text { Increase }\end{array}$ \\
\hline Salt Lake City, UT & 0.046 & $1.87 \%$ & 0.050 & $11.44 \%$ & 0.046 & $0.56 \%$ & 0.047 & $3.51 \%$ \\
\hline San Antonio, TX & 0.072 & $0.70 \%$ & 0.080 & $12.26 \%$ & 0.072 & $0.38 \%$ & 0.076 & $6.88 \%$ \\
\hline San Diego, CA & 0.040 & $1.76 \%$ & 0.053 & $35.57 \%$ & 0.040 & $0.72 \%$ & 0.045 & $15.09 \%$ \\
\hline San Francisco, CA & 0.041 & $0.46 \%$ & 0.045 & $8.87 \%$ & 0.041 & $0.12 \%$ & 0.042 & $2.48 \%$ \\
\hline San Jose, CA & 0.040 & $0.37 \%$ & 0.043 & $8.69 \%$ & 0.040 & $0.09 \%$ & 0.041 & $2.10 \%$ \\
\hline Seattle-Everett, WA & 0.052 & $1.11 \%$ & 0.058 & $12.31 \%$ & 0.052 & $0.50 \%$ & 0.055 & $5.60 \%$ \\
\hline St. Louis, MO & 0.050 & $2.55 \%$ & 0.059 & $19.77 \%$ & 0.050 & $1.01 \%$ & 0.053 & $7.90 \%$ \\
\hline Tampa-St. Petersburg, FL & 0.061 & $0.76 \%$ & 0.069 & $13.71 \%$ & 0.061 & $0.48 \%$ & 0.066 & $8.79 \%$ \\
\hline Washington, DC & 0.043 & $4.93 \%$ & 0.053 & $27.95 \%$ & 0.042 & $2.06 \%$ & 0.046 & $11.70 \%$ \\
\hline
\end{tabular}

Notes: The source is authors' calculations using a marginal tax rate of $25 \%$ plus the top state income tax rates for states that allow the MID, average metropolitan area mortgage interest rate, maintenance costs, property tax rate, and share debt financed. House price inflation of $3.8 \%$ opportunity cost of equity of $6 \%$ is given in all areas. $(1-s)$ and $S q$ parameters from Exhibit 2. See the Appendix for metro area definitions. User cost represents the average annual cost of owning a home per dollar of home purchased; for the 3,000 sq. $\mathrm{ft}$. cap, this relies on the assumption that the marginal cost of square footage is constant.

When including those that have no change in tax preference, the simulated user cost increase is a modest $1.17 \%$ annually.

The clawback proposal would have a substantial effect on the annual cost of home ownership for homes over 3,000 square feet; however, most of this increase would be due to the feature of the proposal that removes the deduction on the entire home rather than the marginal square footage only. To get an idea of how much of the cost change would be due to clawback and how much would be due to the 3,000 square foot limit on the MID, I compare the user cost changes to the flat 3,000 square foot cap, shown in the last four columns of Exhibit 3. Nationally, the flat cap would increase the annual cost of home ownership for homes over the cap by $7.8 \%$, less than half of the increase under the clawback proposal. The user cost increase is substantially lower when I calculate the average cost change using all homes, showing an average annual cost increase of less than $1 \%$.

Limiting the MID affects metropolitan areas quite differently, both in terms of the percentage of homes that lose some tax preferred status and the annual cost of homeownership. Column (2) in Exhibit 2 shows the percentage of homes that would lose tax preferred status with a 3,000 square foot cap on the MID in each of the 46 metropolitan areas in the AHS; Exhibit 5 displays this information in a map. The percentage of homes over 3,000 square feet ranges from a low of $4.25 \%$ in New York, New York to a high of $17.6 \%$ in Washington, D.C. The median city, Cincinnati, Ohio has about $8.5 \%$ of homes over 3,000 square feet that would lose some tax-preferred status. 
Exhibit 4. Home Price Declines Across Metro Areas

\begin{tabular}{|c|c|c|c|c|}
\hline & \multicolumn{2}{|c|}{ Clawback Proposal } & \multicolumn{2}{|c|}{ Flat 3,000 Sq. Ft. Cap } \\
\hline & Metro Average & $\begin{array}{l}\text { Only Homes } \\
\text { Over Cap }\end{array}$ & Metro Average & $\begin{array}{l}\text { Only Homes } \\
\text { Over Cap }\end{array}$ \\
\hline & (1) & (2) & (3) & (4) \\
\hline NATIONAL & $-\$ 3,566$ & $-\$ 67,834$ & $-\$ 1,564$ & $-\$ 33,507$ \\
\hline Anaheim-Santa Ana, CA & $-\$ 6,752$ & $-\$ 174,920$ & $-\$ 2,830$ & $-\$ 87,080$ \\
\hline Atlanta, GA & $-\$ 8,767$ & $-\$ 94,653$ & $-\$ 4,062$ & $-\$ 48,089$ \\
\hline Baltimore, MD & $-\$ 8,102$ & $-\$ 89,366$ & $-\$ 3,726$ & $-\$ 45,241$ \\
\hline Birmingham, AL & $-\$ 1,036$ & $-\$ 19,041$ & $-\$ 323$ & $-\$ 6,098$ \\
\hline Boston, MA & $-\$ 3,740$ & $-\$ 61,132$ & $-\$ 1,611$ & $-\$ 28,403$ \\
\hline Buffalo, NY & $-\$ 1,397$ & $-\$ 30,950$ & $-\$ 559$ & $-\$ 13,899$ \\
\hline Charlotte, NC & $-\$ 5,193$ & $-\$ 88,591$ & $-\$ 2,432$ & $-\$ 47,348$ \\
\hline Chicago, IL & $-\$ 2,226$ & $-\$ 47,074$ & $-\$ 612$ & $-\$ 27,532$ \\
\hline Cincinnati, $\mathrm{OH}$ & $-\$ 692$ & $-\$ 15,481$ & $-\$ 219$ & $-\$ 5,104$ \\
\hline Cleveland, $\mathrm{OH}$ & $-\$ 1,294$ & $-\$ 25,071$ & $-\$ 564$ & $-\$ 11,650$ \\
\hline Columbus, $\mathrm{OH}$ & $-\$ 1,836$ & $-\$ 43,037$ & $-\$ 833$ & $-\$ 20,906$ \\
\hline Dallas, TX & $-\$ 2,525$ & $-\$ 45,740$ & $-\$ 1,108$ & $-\$ 21,879$ \\
\hline Denver, CO & $-\$ 7,723$ & $-\$ 90,233$ & $-\$ 2,995$ & $-\$ 39,173$ \\
\hline Detroit, MI & $-\$ 2,411$ & $-\$ 41,752$ & $-\$ 1,156$ & $-\$ 22,734$ \\
\hline Ft. Worth-Arlington, TX & $-\$ 1,686$ & $-\$ 38,063$ & $-\$ 798$ & $-\$ 19,772$ \\
\hline Hartford, CT & $-\$ 1,692$ & $-\$ 31,272$ & $-\$ 823$ & $-\$ 16,181$ \\
\hline Houston, TX & $-\$ 1,855$ & $-\$ 33,573$ & $-\$ 863$ & $-\$ 17,074$ \\
\hline Indianapolis, IN & $-\$ 2,747$ & $-\$ 45,524$ & $-\$ 1,260$ & $-\$ 22,537$ \\
\hline Kansas City, MO & $-\$ 4,170$ & $-\$ 67,275$ & $-\$ 1,849$ & $-\$ 33,363$ \\
\hline Los Angeles, CA & $-\$ 5,081$ & $-\$ 151,159$ & $-\$ 2,672$ & $-\$ 89,985$ \\
\hline Memphis, TN & $-\$ 2,222$ & $-\$ 42,387$ & $-\$ 961$ & $-\$ 19,962$ \\
\hline Miami-Ft. Lauderdale, FL & $-\$ 4,340$ & $-\$ 55,580$ & $-\$ 2,131$ & $-\$ 29,850$ \\
\hline Milwaukee, WI & $-\$ 3,490$ & $-\$ 40,597$ & $-\$ 1,319$ & $-\$ 16,997$ \\
\hline Minneapolis-St. Paul, MN & $-\$ 5,464$ & $-\$ 69,212$ & $-\$ 2,324$ & $-\$ 33,156$ \\
\hline New Orleans, LA & $-\$ 2,648$ & $-\$ 61,145$ & $-\$ 1,352$ & $-\$ 34,335$ \\
\hline New York, NY & $-\$ 2,289$ & $-\$ 89,586$ & $-\$ 1,274$ & $-\$ 58,572$ \\
\hline Norfolk, VA & $-\$ 1,262$ & $-\$ 44,433$ & $-\$ 343$ & $-\$ 12,741$ \\
\hline Oakland, CA & $-\$ 2,521$ & $-\$ 84,155$ & $-\$ 663$ & $-\$ 24,070$ \\
\hline Oklahoma City, OK & $-\$ 2,305$ & $-\$ 72,628$ & $-\$ 1,006$ & $-\$ 36,049$ \\
\hline Philadelphia, PA & $-\$ 3,681$ & $-\$ 47,830$ & $-\$ 2,078$ & $-\$ 28,329$ \\
\hline Phoenix, AZ & $-\$ 5,319$ & $-\$ 124,704$ & $-\$ 2,910$ & $-\$ 74,340$ \\
\hline Pittsburgh, PA & $-\$ 885$ & $-\$ 18,394$ & $-\$ 394$ & $-\$ 8,571$ \\
\hline Portland, OR & $-\$ 4,140$ & $-\$ 91,488$ & $-\$ 1,818$ & $-\$ 45,631$ \\
\hline Providence, RI & $-\$ 446$ & $-\$ 17,532$ & $-\$ 132$ & $-\$ 5,581$ \\
\hline Riverside, CA & $-\$ 6,167$ & $-\$ 181,037$ & $-\$ 2,748$ & $-\$ 94,604$ \\
\hline Rochester, NY & $-\$ 348$ & $-\$ 10,071$ & $-\$ 95$ & $-\$ 2,918$ \\
\hline Sacramento, CA & $-\$ 4,713$ & $-\$ 117,251$ & $-\$ 2,411$ & $-\$ 66,881$ \\
\hline Salt Lake City, UT & $-\$ 4,067$ & $-\$ 45,404$ & $-\$ 1,242$ & $-\$ 15,002$ \\
\hline San Antonio, TX & $-\$ 894$ & $-\$ 28,047$ & $-\$ 491$ & $-\$ 16,524$ \\
\hline
\end{tabular}


Exhibit 4. Home Price Declines Across Metro Areas (continued)

\begin{tabular}{llllll} 
& \multicolumn{2}{l}{ Clawback Proposal } & & \multicolumn{2}{l}{ Flat 3,000 Sq. Ft. Cap } \\
\cline { 2 - 3 } & Metro Average & $\begin{array}{l}\text { Only Homes } \\
\text { Over Cap }\end{array}$ & & Metro Average & $\begin{array}{l}\text { Only Homes } \\
\text { Over Cap }\end{array}$ \\
\hline & $(1)$ & $(2)$ & $-\$ 196,171$ & $-\$ 2,683$ & $(4)$ \\
\hline San Diego, CA & $-\$ 6,452$ & $-\$ 61,694$ & & $-\$ 471$ & $-\$ 98,039$ \\
San Francisco, CA & $-\$ 1,733$ & $-\$ 68,218$ & & $-\$ 374$ & $-\$ 18,318$ \\
San Jose, CA & $-\$ 1,584$ & $-\$ 51,452$ & & $-\$ 1,159$ & $-\$ 17,538$ \\
Seattle-Everett, WA & $-\$ 2,578$ & $-\$ 59,168$ & & $-\$ 1,792$ & $-\$ 24,886$ \\
St. Louis, MO & $-\$ 4,458$ & $-\$ 13,066$ & & $-\$ 849$ & $-\$ 26,254$ \\
Tampa-St. Petersburg, FL & $-\$ 1,347$ & $-\$ 165,198$ & & $-\$ 7,621$ & $-\$ 28,870$ \\
Washington, DC & $-\$ 17,762$ & $-\$ 79,246$ \\
\hline
\end{tabular}

Notes: The source is authors' calculations using a marginal tax rate of $25 \%$ plus the top state income tax rates for states that allow the MID, average metropolitan area mortgage interest rate, maintenance costs, property tax rate, and share debt financed. House price inflation of $3.8 \%$ opportunity cost of equity of $6 \%$ is given in all areas. $(1-s)$ and $S q$ parameters are from Exhibit 2. Metro area rents are median rents from the 2009 American Community Survey; rents for homes over the cap are taken as double the metro area median. See the Appendix for metro area definitions.

Exhibit 5. Percentage of Homes over 3,000 Square Feet

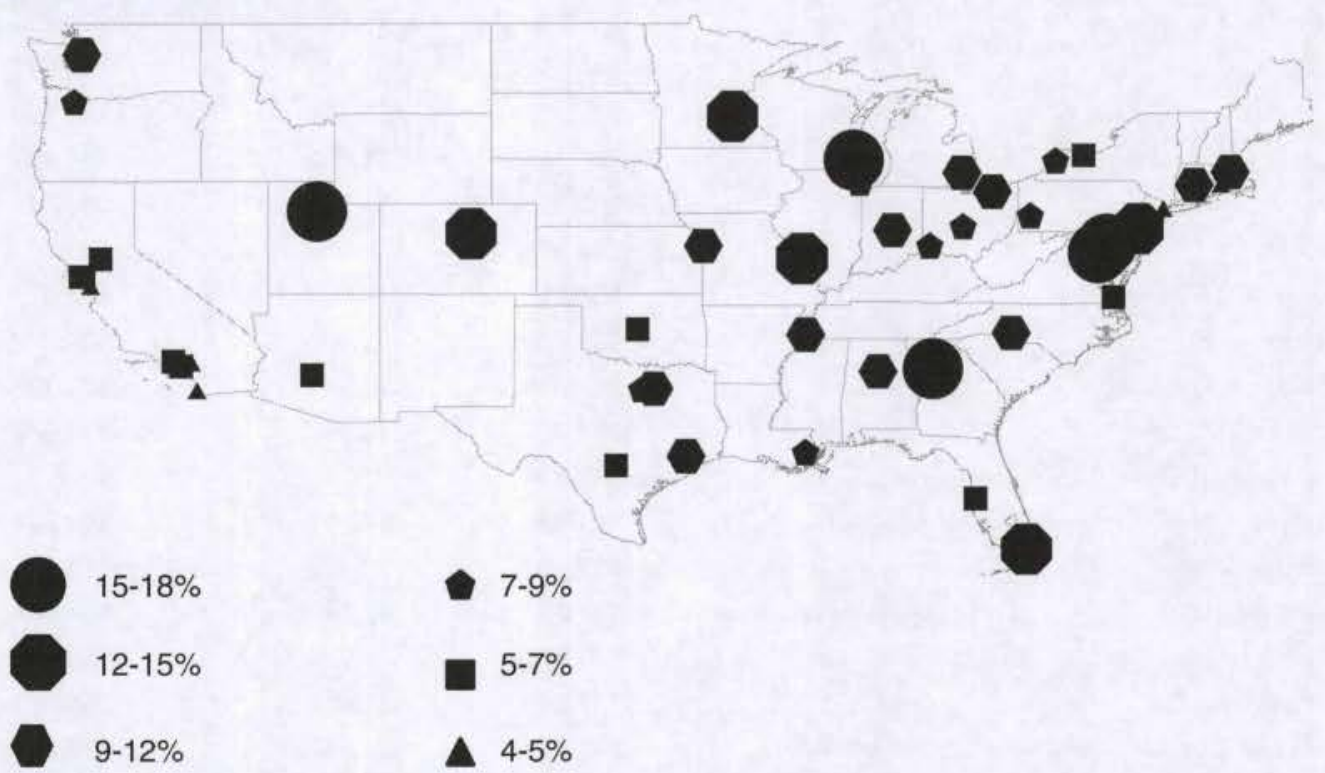

Source: Data from American Housing Survey, Map generated using ArcGIS software. 
In addition to the percentage of homes subject to the cap, user cost would also change because of the intensity of exposure to the cap. The $S q$ and $(1-s)$ parameters reflect the intensity of exposure to the cap. Exhibit 2 shows the substantial variation in the $S q$ and $(1-s)$ parameters across metropolitan areas. The size of the $S q$ and $(1-s)$ parameters also varies depending on if I leave in the homes below the cap or calculate them based only on the homes over 3,000 square feet. The difference in the size of the parameters reflects how much of the housing stock would be exposed to each policy across cities.

The average change in user cost for homes exposed to the cap under the clawback proposal varies substantially across metropolitan areas. The simulations show the smallest user cost change in Rochester, New York at $4.78 \%$ increase in the average annual cost of homeownership. According to the simulations, the largest user cost change under the clawback proposal would occur in Riverside, California. The user cost increase in Riverside would be a whopping $38.8 \%$. The median increase in the user cost of housing under the clawback proposal would be in the Detroit, Michigan metropolitan area, with an expected increase of about $15.37 \%$ in the annual cost of owning a home.

The user cost increases under the clawback proposal are highest in southern California and the Washington, D.C. area. Cities in California have some of the highest expected cost increases, with Anaheim, Los Angeles, Riverside, and San Diego all experiencing greater than a $28 \%$ rise in user cost. Midwestern cities tend to be closer to the median, with St. Louis, Missouri, Milwaukee, Wisconsin, Columbus, Ohio, Indianapolis, Indiana, and Minneapolis, Minnesota all between a $15 \%$ and $20 \%$ increase in user cost. In addition, residents over the cap in most cities would experience at least a $10 \%$ increase in the annual cost of homeownership with the exceptions being Birmingham, Alabama, Cincinnati, Ohio, Norfolk, Virginia, Pittsburgh, Pennsylvania, Providence, Rhode Island, Rochester, New York, San Francisco, California, and San Jose, California.

To separate the effects of the clawback and a 3,000 square foot cap, I simulate the user cost change for a cap that removes the deduction on only the marginal square footage over 3,000. The last four columns of Exhibit 3 present the simulation results for the flat 3,000 square foot cap using only variation from the home size differences across cities. As with the clawback proposal, the user cost changes would vary substantially across metropolitan areas. The smallest user cost changes under the flat cap proposal are in many of the same areas as the clawback proposal: Rochester, New York, Birmingham, Alabama, Providence, Rhode Island, and Cincinnati, Ohio all have an average annual cost increase of less than $2 \%$. This overlap suggests that the more compact home-size distribution would drive user cost changes in these cities.

The largest user cost changes under the flat cap proposal would occur in cities that are quite similar to those that would experience the largest increase under the clawback proposal. Under the flat cap proposal, Riverside, California would experience the largest user cost increase, $\mathbf{1 7 . 2} \%$ annually. Homes over the cap in Phoenix, Arizona and San Diego, Anaheim, and Los Angeles, California would all experience a user cost increase over $30 \%$. These cities are also in the upper part of the user cost increase distribution for the clawback proposal, suggesting that the combined effects of home size and clawback are important. 
Using an empirical estimate of the elasticity of home size with respect to tax-induced user cost changes of -1.4 produced by Hanson (2010), the user cost changes would induce changes in home size as large as $50 \%$ for homes above the cap in some markets. I expect that most changes in home size would occur over the long run as new construction becomes smaller and larger homes are subdivided into townhomes or condominiums. Taking the elasticity estimate in Hanson (2010), the user cost estimates presented here, suggest that the clawback proposal would eventually reduce the average size of homes nationally by about $2.2 \%$ or 54 square feet, and the flat cap would reduce the size of homes by about $1 \%$, or 25 square feet. The driver behind the size declines will be a reduction in the size of homes over the cap, where the size declines would be substantial.

\section{Home Price Changes}

To calculate price changes from the proposed MID limits, I use equations (6) and (9), which follow directly from the user cost model. Combining the user cost changes with data on rents allows me to estimate how the proposed policies might affect home prices. I use median rent data from the 2009 American Community Survey to estimate the price effect for the metropolitan area average, and then double the median rent as an approximation for price effects on homes over the 3,000 square foot limit. All other parameters are the same as those used to calculate user cost changes. I expect that if either proposal were to become law, price declines would dominate any behavioral effects on home size purchase in the short run. Over a longer time period, with building smaller new homes or existing homes being subdivided, size declines would take hold.

The national average price reduction from the clawback style cap would be $\$ 3,566$, with substantial variation across metropolitan areas, as shown in Exhibit 4 . By far the largest price reduction at the metropolitan area level would be in Washington, D.C. at $\$ 17,762$ due to the larger size of homes, higher rental rates, and high marginal tax rate. At the other end of the spectrum, Rochester, New York would have less than a $\$ 350$ decline for metro area average prices, and Cincinnati, Ohio, Pittsburgh, Pennsylvania, Providence, Rhode Island, and San Antonio, Texas would have less than a \$1,000 decline on average.

For homes over the proposed clawback cap, the expected price declines would be sizable, as shown in column (2) of Exhibit 4. Recall that the clawback proposal would penalize the entire home if it is larger than the limit, not merely penalizing size on the margin. The national average price decline for homes over the cap for the clawback proposal would be $\$ 67,834$, and again metropolitan areas would have substantial differences. The upper end of the price decline distribution would include several metropolitan areas with expected declines of more than \$150,000 (Anaheim, Los Angeles, Riverside, San Diego, and Washington D.C.). Even the smallest predicted price declines are more than $\$ 10,000$, with most declines in the $\$ 40,000$ to $\$ 60,000$ range.

The flat cap proposal would induce more modest price declines, due to only penalizing the marginal size over the 3,000 square foot limit. Nationally, this proposal would cause a $\$ 1,564$ decline in median home prices, again with varying degrees of severity across metropolitan areas. The primary feature of this proposal is the price decline depends on how much larger than the cap homes are, so the distribution of declines would be 
somewhat different than the clawback distribution. Washington, D.C. again would show the largest decline at $\$ 7,621$, followed by Atlanta at $\$ 4,062$. Several metropolitan areas would have less than a $\$ 1,000$ price decline, with the smallest declines in many of the same areas that are least effected by the clawback proposal.

For homes over the proposed flat cap, expected price declines are roughly half the size as the clawback cap, which indicates that penalizing the entire home rather than marginal square footage would drive about half of the price declines under the clawback proposal. Nationally, homes over the flat cap would experience a $\$ 33,507$ decline in price, with declines ranging from \$98,039 in San Diego, California to \$2,918 in Rochester, New York.

\section{Policy Considerations}

Limiting the MID based on the square footage of a home would represent a major change in federal tax policy toward housing. There are important aspects of this policy to consider besides how it changes the annual cost of homeownership and home prices. Some considerations relate to the user cost, such as how the policy would affect home sizes, while others are practical in nature, such as how the Internal Revenue Service would implement such a policy.

The direct effect of the user cost increase is a reduction in square footage consumed over the limit. The size of the response depends on whether home purchasers finance marginal square footage with debt or equity, as the MID limit would only affect the price of debt financed housing. Some homes may be able to adjust more easily than others to the user cost increase, most notably new construction where the size is not yet determined. For existing homes, it is possible that large units could convert to condominiums or townhomes, but some homes may not be able to adjust size in a cost-effective way.

The policy change will reduce home values on existing homes that cannot adjust square footage. Solving the user cost equation for $P_{H}$ instead of $R$ shows the magnitude of the reduction in value. To lessen the burden on existing owners of large homes, policymakers may want to consider phasing in such a policy or implementing a larger cap for existing homes than new construction. ${ }^{13}$ The user cost model predicts an abrupt and severe change in $P_{H}$; however, the changing debt-to-equity ratio, which declines as a home owner pays off the mortgage, suggests the change may not be as severe as the simple model indicates.

One practical concern is the choice of a home's components that are considered as part of the square footage calculation. Policymakers would have to decide if basement and garage areas, partial outdoor areas such as three-season rooms, and attic space are included in the square footage calculation. All of these choices would add complexity to the income tax code. If some of these were not included in the square footage, substitution between them and other areas would occur, resulting in inefficiency. One such trade-off, for example, could be substitution from additional closet space to more attic space if attic space were not included in the square footage calculation. Homeowners may also substitute along quality dimensions, choosing more elaborate home fixtures or furnishings instead of additional square footage.

Finally, limiting the MID based on the square footage of a home requires the IRS to somehow monitor compliance. First, the IRS needs to determine how to allocate square 
footage across debt and equity financed housing. The second problem is how the IRS obtains information on the square footage of a home. Self-reported square footage is likely to be unreliable, so the agency may have to consider relying on third-party reporting, possibly from county property tax assessors or builders. These problems could impose non-trivial administrative costs that cut into any revenues gained from limiting the MID and would add additional complexity to the tax code.

\section{Conclusion}

In this paper, I extend the standard user cost of housing model to include a cap on mortgage interest deductibility based on home size. I use the extended model to simulate the user cost effects of two different MID limits: a clawback proposal and a flat cap proposal. The simulations show how each policy affects the average user cost of housing across a range of metropolitan areas. Under the flat cap, the user cost increase across metropolitan areas would range from a low of a $1.34 \%$ in Rochester, New York to a high of $17.12 \%$ in Riverside, California. Under the clawback proposal, the user cost change across metropolitan areas would range from a low of $4.78 \%$ in Rochester, New York to a high of $38.83 \%$ in Riverside, California. These user cost changes translate into expected price declines on homes exposed to the clawback cap ranging from $\$ 196,171$ in San Diego, California to a decline of $\$ 10,071$ in Rochester, New York. Expected price declines under the flat cap would be about half the magnitude as declines under the clawback proposal.

I provide a model and simulation results that are useful when considering the impact of proposals that would limit the MID by the size of home purchased. There is substantial difference between a policy that removes the marginal deduction and a policy that removes the deduction on the entire home (clawback). I show that both the number homes affected by the policy, and the intensity those homes are exposed to the cap affect housing affordability. The simulations presented here suggest that limiting the MID by the size of home induces a substantial increase in the user cost of housing, as well as declines in home prices, and that these changes are distributed unevenly across metropolitan areas.

Appendix

\section{Exhibit 1A. AHS Survey Geography, Timing, and Sample Size}

\begin{tabular}{llll} 
& Areas Included in Survey & Year Surveyed & Sample Size \\
\hline Anaheim-Santa Ana, CA & $\begin{array}{l}\text { Anaheim city, Santa Ana city, Garden Grove } \\
\text { city }\end{array}$ & 2002 & 4,911 \\
Atlanta, GA & Atlanta city, DeKalb County, Cobb County & 2004 & 5,132 \\
Baltimore, MD & $\begin{array}{l}\text { Baltimore city, Baltimore County, Anne } \\
\text { Arundel County }\end{array}$ & 2007 & 2,733 \\
Birmingham, AL & Jefferson County, Shelby County & 1998 & 5,066 \\
Boston, MA & Boston city, Cambridge city, Lynn city & 2007 & 2,771 \\
Buffalo, NY & Erie County, Niagara Falls City & 2002 & 4,555 \\
\hline
\end{tabular}




\section{Appendix}

Exhibit 1A. AHS Survey Geography, Timing, and Sample Size (continued)

\begin{tabular}{|c|c|c|c|}
\hline & Areas Included in Survey & Year Surveyed & Sample Size \\
\hline Charlotte, NC & $\begin{array}{l}\text { Mecklenburg County, NC, Gaston County, NC, } \\
\text { York County, SC }\end{array}$ & 2002 & 5,119 \\
\hline Chicago, $\mathrm{IL}^{\mathrm{B}}$ & Cook County, DuPage County & 2003 & 2,863 \\
\hline Cincinnati, $\mathrm{OH}$ & Hamilton County, $\mathrm{OH}$ Kenton County & 1998 & 5,041 \\
\hline Cleveland, $\mathrm{OH}$ & Cuyahoga County, Lake County & 2004 & 4,722 \\
\hline Columbus, $\mathrm{OH}$ & Franklin County, Licking County & 2002 & 4,936 \\
\hline Dallas, TX & Dallas County, Collin County & 2002 & 5,743 \\
\hline Denver, CO & $\begin{array}{l}\text { Denver city, Jefferson County, Arapahoe } \\
\text { County }\end{array}$ & 2004 & 4,834 \\
\hline Detroit, $\mathrm{Ml}^{\mathrm{a}}$ & Wayne County, Oakland County & 2003 & 2,186 \\
\hline Ft. Worth-Arlington, TX & Tarrant County & 2002 & 5,052 \\
\hline Hartford, CT & Hartford city, New Britain city, Bristol city & 2004 & 4,728 \\
\hline Houston, TX & Harris County, Fort Bend County & 2007 & 2,861 \\
\hline Indianapolis, IN & $\begin{array}{l}\text { Indianapolis city, Hamilton County, Johnson } \\
\text { County }\end{array}$ & 2004 & 4,814 \\
\hline Kansas City, MO-KS & $\begin{array}{l}\text { Kansas City city, MO, Kansas City city, KS } \\
\text { Jackson County, MO }\end{array}$ & 2002 & 4,830 \\
\hline Los Angeles, $\mathrm{CA}^{\mathrm{a}}$ & Los Angeles County & 2003 & 3,717 \\
\hline Memphis, TN & $\begin{array}{l}\text { Memphis city, Shelby County, TN DeSoto } \\
\text { County, MS }\end{array}$ & 2004 & 4,644 \\
\hline Miami-Ft. Lauderdale, FL & Dade County, Ft. Lauderdale city & 2007 & 2,647 \\
\hline Milwaukee, WI & Milwaukee County, Waukesha County & 2002 & 4,823 \\
\hline Minneapolis-St. Paul, MN & St. Paul city, Hennipin County & 2007 & 2,847 \\
\hline New Orleans, LA & $\begin{array}{l}\text { New Orleans city, Jefferson Parish, St. } \\
\text { Tammany Parish }\end{array}$ & 2004 & 4,516 \\
\hline New York, NYa & $\begin{array}{l}\text { New York city, Nassau County, Suffolk } \\
\text { County }\end{array}$ & 2003 & 2,103 \\
\hline Norfolk, VA & $\begin{array}{l}\text { Norfolk city, Virginia Beach city, Newport } \\
\text { News city }\end{array}$ & 1998 & 4,861 \\
\hline Oakland, CA & Alameda County, Contra Costa County & 1998 & 4,753 \\
\hline Oklahoma City, OK & $\begin{array}{l}\text { Oklahoma City city, Oklahoma County, } \\
\text { Cleveland County }\end{array}$ & 2004 & 4,829 \\
\hline Philadelphia, $\mathrm{PA}^{\mathrm{a}}$ & $\begin{array}{l}\text { Philadelphia city Montgomery County, } \\
\text { Delaware County, }\end{array}$ & 2003 & 2,353 \\
\hline Phoenix, AZ & Maricopa County & 2002 & 5,056 \\
\hline Pittsburgh, PA & $\begin{array}{l}\text { Pittsburgh city, Allegheny County, } \\
\text { Westmoreland County }\end{array}$ & 2004 & 4,723 \\
\hline Portland, OR & $\begin{array}{l}\text { Portland city, Multnomah County, OR } \\
\text { Washington County, OR }\end{array}$ & 2002 & 4,917 \\
\hline Providence, RI & $\begin{array}{l}\text { Providence city, RI, Warwick city, RI, Cranston } \\
\text { city, RI }\end{array}$ & 1998 & 4,724 \\
\hline Riverside, CA & $\begin{array}{l}\text { Riverside County, Riverside City, San } \\
\text { Bernardino city }\end{array}$ & 2002 & 4,932 \\
\hline
\end{tabular}




\section{Appendix}

Exhibit 1A. AHS Survey Geography, Timing, and Sample Size
(continued)

Areas Included in Survey

Year Surveyed Sample Size

Rochester, NY

Sacramento, CA

Salt Lake City, UT

San Antonio, TX

San Diego, CA

San Francisco, CA

San Jose, CA

Seattle, WA

St. Louis, MO

Tampa-St. Petersburg, FL

Washington, DC

Monroe County, Ontario County
Sacramento County, Placer County
Davis County, Salt Lake County
Bexar County, Guadalupe County
San Diego County, San Diego City
Marin County, San Francisco city, San Mateo
County

Santa Clara County

King County, Snohomish County

St. Louis city, St. Louis County, St. Clair

County

1998

2004

4,763

1998

4,728

2004

4,878

2002

4,863

1998

4,872

4,813

1998

4,804

2004

4,731

2004

4,741

2007

3,053

2,781

District of Columbia, Prince George's County, 2007 MD, Fairfax County, VA

${ }^{a}$ Indicates Data from National AHS survey.

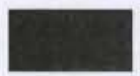

\section{Endnotes}

${ }^{1}$ Under current law, the MID is limited to interest paid on a mortgage of $\$ 1,000,000$.

${ }^{2}$ For details of Dingell's proposal not discussed here, see: http://www.house.gov/dingell/ carbonTaxSummary.shtml.

${ }^{3}$ The average square footage for new single-family homes peaked in 2007 at 2,521 .

${ }^{4}$ For a recent review of the literature on tax policy and housing, see Hendershott and White (2000) and Anderson, Clemens, and Hanson (2007). Also see Bruce and Holtz-Eakin (1999) for a discussion of the economic effects of eliminating housing tax preferences through a shift to consumption-based taxation.

5 For variants of the user cost model, see Rosen (1979a, 1979b, 1985), Poterba $(1984,1992)$, Green and Vandell (1999), Glaeser and Shapiro (2003), Himmelberg, Mayer and Sinai (2005), and Anderson, Clemens, and Hanson (2007).

${ }^{6}$ If the mortgage interest rate on square footage increases (decreases) as the amount borrowed increases, my model will understate (overstate) the user cost increase induced by the policy.

7 The definition of metropolitan area used by the AHS is not consistent with the definition used by other agencies; therefore, I list the geographic units in each metropolitan area in Appendix Table Exhibit 1A.

8 The national survey is conducted in every odd-numbered year, collecting data from a fixed sample of about 50,000 homes, and adding newly constructed units. The metropolitan survey is conducted in even-numbered years, cycling through a set of $\mathbf{4 1}$ metropolitan areas, surveying each one about once every six years (ICF, 2006).

${ }^{9}$ For example, there is not a separate recent metropolitan area survey for New York, Los Angeles, Detroit, Philadelphia, or Chicago, so I draw my sample of these cities from the national survey. 
10 The AHS instructs occupants to include all rooms, hallways, and finished basements and attics in this estimate. They also explicitly ask the occupant not to consider unfinished attics, carports, attached garages, and porches that are not protected from the elements and heated.

11 The AHS asks owners the original amount of their mortgage and the interest rate on their mortgage. I use the reported value of the house to create a measure of the share that is debt financed and use the reported mortgage interest rate directly. Values are created individually and averaged for the metropolitan area to create the parameters. Values for the share of debt financing greater than one, which occur due to home equity lending, are adjusted to equal one.

12 The AHS asks owners how much per year they pay in property taxes and how much per year they spend on maintenance. I divide each of these by the reported value of the house to get a rate for $m$ and $\tau_{p}$. Values are created individually and averaged for the metropolitan area to create the parameters.

${ }^{13}$ For example, President Bush's Tax Reform Advisory Panel recommended a four-year phasein of MID caps based on area home values for pre-existing mortgages. They suggested that the MID mortgage limit be gradually reduced from the present $\$ 1$ million to $\$ 500,000$ over three years $(\$ 900,000$ in year one, $\$ 700,000$ in year two, and $\$ 500,000$ in year three). Then, in the fourth year, the deduction is subject to region-specific limits based on area home values.

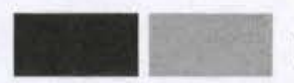

\section{References}

Anderson, J., J. Clemens, and A. Hanson. Capping the Mortgage Interest Deduction. National Tax Journal, 2007, 60:4, 769-85.

Bruce, D. and D. Holtz-Eakin. Fundamental Tax Reform and Residential Housing. Journal of Housing Economics, 1999, 8:4, 249-71.

Executive Office of the President. Office of Management and Budget. Analytical Perspectives, Budget of the United States Government Fiscal Year 2009. Washington, DC: U.S. Government Printing Office, 2008.

Follain, J. and L. Melamed. The False Messiah of Tax Policy: What Elimination of the Home Mortgage Interest Deduction Promises and a Careful Look at What It Delivers. Journal of Housing Research, 1998, 9:2, 179-99.

Glaeser, E. and J. Shapiro. The Benefits of the Home Mortgage Interest Deduction. Tax Policy and the Economy, 2003, 17, 37-82.

Green, R. and K. Vandell. Giving Households Credit: How Changes in the U.S. Tax Code Could Promote Homeownership. Regional Science and Urban Economics, 1999, 29:4, 41944 .

Hanson, A. Size of Home, Homeownership, and the Mortgage Interest Deduction. Unpublished manuscript, 2010.

- The Incidence of the Mortgage Interest Deduction: Evidence from the Market for Home Purchase Loans. Public Finance Review, 2012, 40:3, 339-59.

Hendershott, P. and M. White. Taxing and Subsidizing Housing Investment: The Rise and Fall of Housing's Favored Status. National Bureau of Economic Research working paper $\$ 7928$, 2000.

Himmelberg, C., C. Mayer, and T. Sinai. Assessing High House Prices: Bubbles, Fundamentals, and Misperceptions. Journal of Economic Perspectives, 2005, 19:4, 67-92.

ICF International. Codebook for the American Housing Survey, Public Use File: 1997 and Later. October, 2006. 
Poterba, J. Tax Subsidies to Owner-Occupied Housing: An Asset Market Approach. Quarterly Journal of Economics, 1984, 99:4, 729-52.

- Taxation and Housing: Old Questions, New Answers. American Economic Review, 1992, $82: 2,237-42$.

Poterba, J. and T. Sinai. Income Tax Provisions Affecting Owner-Occupied Housing: Revenue Costs and Incentive Effects. National Bureau of Economic Research Working Paper \#14253, 2008.

Rosen, H. Housing Decisions and the U.S. Income Tax: An Econometric Analysis. Journal of Public Economics, 1979a, 11:1, 1-23.

- Owner Occupied Housing and the Federal Income Tax: Estimates and Simulations. Journal of Urban Economics, 1979b, 6:2, 247-66.

- Housing Subsidies: Effects on Housing Decisions, Efficiency, and Equity. In Handbook of Public Economics, Volume 1. M. Feldstein and A. Auerbach (eds.). Amsterdam: NorthHolland Press, 1985.

Woodward, S. and J. Weicher. Goring the Wrong Ox: A Defense of the Mortgage Interest Deduction. National Tax Journal, 1989, 2:3, 301-13.

Andrew Hanson, Marquette University, Milwaukee, WI 53201 or andrew.r.hanson@ marquette.edu. 